\title{
Australia's Economic Market Improved by Technological Innovation
}

\author{
Qin $\mathrm{Ru} \mathrm{HOU}^{1}$
}

\author{
${ }^{1}$ UNSW Sydney, High St, Kensington, NSW 2052, Australia \\ qinru.hou@student.unsw.edu.au
}

\begin{abstract}
Our literature review focuses on the technological innovation construct of economic growth in Australia. Drawing broadly from the technical innovation and economic growth literature crossing, we suggest positions about the antecedents and technical innovation outcomes. We also identify issues and questions to address them in the future and disclose suggestions for future research and practice. In this paper, we proposed that the technological innovation could impact the Australia's economic positively, which would offer more potential research opportunities in the future work.
\end{abstract}

Keywords: Technical innovation, economic market

\section{INTRODUCTION}

Based on the higher labour efficiency and high-level usage of material in a developed country, people ask, what is the next chapter in our economic boost? Australian Government Department of Industry [1] highlighted the importance of technical innovation. In the world of a developed country, corporations and government have strong incentives to improve technology. More than two-thirds of Australian corporations focus on innovation culture preference. Much has been written about the relationship between technological innovation and economic growth, suggesting the approaches government should take. Therefore, a complete review of the critical social science literature that has linked technological innovation and economic development illustrates why technological innovation is considered a significant force in economic growth and focuses on some of the most distinctive features of Australian invention in highly industrialized economies.

\section{MATERIAL AND METHOD}

Two widely influential economists, John Maynard Keynes and Joseph Schumpeter apply the exceptional views of the relationship between technical innovation and the economic market. This section is devoted to describing John Maynard Keynes and Joseph Schumpeter's theory on technical innovation.

\subsection{John Maynard Keynes}

During the early 20th century, John Maynard Keynes (1883 - 1946) was considered a famous British economist worldwide for his two main contributions to the economy's change. Firstly, Keynesian economic theories establish modern macroeconomics, including the General Theory of Employment, Interest and Money. Keynes believed that aggregate demand is the primary driving influence in an economy: the total consumption by individual households, businesses, and government [12]. Consequently, the level of aggregate demand defines the sum of production and employment.

Secondly, the government is the main influence on economic growth. Keynes is the most famous economist to suggest that government should intervene in the economy, rather than the free market. Keynes concluded that the government policy is advised by the elite and civil servants to ensure government market effectiveness [9].

Keynes viewed that a healthy economy keeps longterm stability in static equilibrium. Thus, the unemployment rate and inflation rate are in balance. The government should regulate this balance rather than leaving it as an unrestricted market. Keynes considered the macroeconomic level that the extended period of low employment causes insufficient overall economic market demand. The high unemployment rate and low productivity have occurred from the absence of market equilibrium, resulting in less funding to invest and spend for individuals. Ultimately, technology and production 
are under established in the economy and led to low economic maturity.

For Keynes's view of the market equilibrium, Keynes proposes that the gross production is equivalent to the aggregate expenditures. Investment and consumption are two opposite forces, although these two forces succeed in the long-term balance unless an external drive intervenes. According to value creation and innovation, the distinct core requirements for economic growth and the employment rate to the equilibrium are notable. Despite this, the equilibrium market is opposing to the creative market. For example, the mobile phone replaces the digital camera in the essential needs. The innovation breaks the long-term relationship upon the inactive equilibrium market.

The rise of competition dramatically influences quality creation. A company is willing to invest in sufficient quality innovation more than insufficient quality creation in the long-term market. Hence, it can achieve its primary objective to acquire greater profits and further competitors within the same industry. Since, the growth of innovation and quality has drawn the business to a stable market [6].

\subsection{Joseph Schumpeter theory}

Joseph Alois Schumpeter (1883 - 1950) was one of the greatest political economists in the same period as John Maynard Keynes. Joseph is a firm supporter of technical innovation. In opposition, Schumpeter's view is entirely separate from Keynesian economics. Schumpeter believes innovation-originated market potential because economic liberalism rejects government intervention as a regulatory role in the economic market. From Schumpeter's perspective, government intervention advances market inflation to suppress innovation. Schumpeter also furthered that the static economic market equilibrium is not fit for technical innovation. Based on economic growth, technological innovation is a framework and the key economic improvement factor. Creative destruction, entrepreneurship and the business cycle are the three foremost contributions to obtain an economic extension.

Schumpeter argued that entrepreneurs should promote various technological innovations in each business cycle. Base on Shionoya [16], entrepreneurs have a vital position in the performance of economic prosperity. Therefore, Schumpeter agreed that the invention accelerates the economic market growth.

Schumpeter proposed that technical innovation is not an automated process, so the agency should actively encourage it [10]. Most of the agencies are corporations because companies are responsible for designing and developing technological innovation [13]. Collaborative entrepreneurship is an example that has positive energy to enhance innovation. Also, it generates a reliable environment for the innovator to create the new product. Therefore, innovation's outcome undoubtedly relates to collaborative entrepreneurship [15].

Based on new technology and innovation, it supports more effective productivity extension in the industry performance. The company with successful technology supersedes the maturity company in the industry.

On the other hand, the lower innovation company limits the profitable growth across diverse industries. Conclusively, the outmoded corporation would fall behind the active market [7]. Schumpeter concluded that entrepreneurship would be a more reliable instrument to better innovation in the market.

\section{THE FACTORS}

There are three positive factors of the technical innovation toward Australia (see Figure. 1 for a summary of the factors).

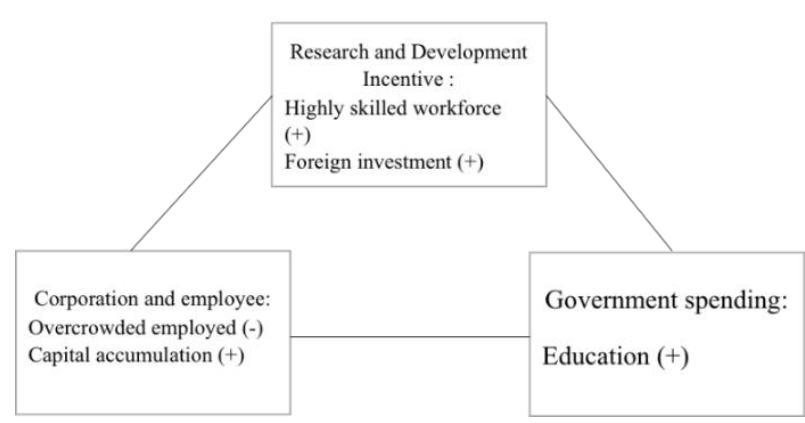

Figure 1. Three positive factors of the technical innovation toward Australia.

The factors used in this work are grounded in the John Maynard Keynes theory. We assume to build on and extend the previous work that has been conducted in this area as well as describing the impact on the Australia's technical innovation.

\subsection{Research and Development Incentive}

The Australian government support technological innovation development. The yearly government report disclosed a direct approximated expenditure of \$2.95 billion into technical innovation from 2013 to 2014. Furthermore, the Australian government extends the \$200 million spendings to incentivise its technological innovation development. There is a $\$ 2$ million annual cash refund payable benefit for the corporation [2]. It is one of the most valuable technological innovation incentives policies. Corporations could reduce up to 125 per cent of the investment expenditure [14]. Therefore, a company can participate in the innovation by spending fewer funds developing a technology.

According to the incentive policy, Australia's company holds the advantage of technological innovation 
and the incentive of technical innovation development is the Australian government's significant economic market subsidies. Hence, this policy provides the corporation to establish the innovation's productivity for the long-term period. It is suitable for the company to deliver satisfactory work and develop technical invention by supporting policy. Therefore, it is a definite relationship between technological modernisation and innovation. The enormous scale of creation increases productive jobs. According to the employment data, the employment ratio has an affirmative effect due to technical innovation. The aggregate employment rate rises 10.8 per cent after November 2013, comparing with the employment ratio in 2013, an additional climb of 2.2 per cent ratio in 2018. On the other side, the unemployment rate has declined from 8.8 per cent to 6.8 per cent in one year. Based upon the innovation industry's data in November 2013, the number of the highly skilled workforce increases 19.4 per cent. The employment rate grew effectively in the past five years, and it is one of Australia's largest expanded industry [3]. The enormous power of production can offset the less raw material resource because technical innovation boosts the productivity in the impoverished region. The massive number of foreign investors is an additional benefit in association with the innovation improvement that attracts foreign investors to spend in the Australian economic market, due to their positive expectations towards the Australian market. Thus, a growing number of foreign investments illustrates a performance to national prestige. It could be evident from the increase of the innovative Australian industry. Therefore, it would enhance technological innovation through aid from foreign investment.

\subsection{Corporation and employee}

Keeping the condition of the innovative industry, it has a more potent strength in the long-term innovation. The creative employee demands higher income, therefore it makes a considerably rise in the labour market. It could increase the quantity of talented and creative workforces when employees have primarily contributed to technical innovation - the grand amount of higher experienced labour entry to the innovative industry. The report estimates that individuals who participate in the labour market increase 10.2 per cent to 2023 [3]. Data reveals the incentive for educated labour to engage in the innovative industry from a more satisfying, productive working atmosphere. Therefore, the unemployment ratio shrinks in the Australian labour market. It generates relief on the other overcrowded employed sector. The outperformance of the labour market indirectly reflects the thriving Australian economic market. Also, creative employees create more ideas in a better innovative environment. Great ideas are based on enhancing technical innovation, then producing creative goods in the market. It is an excellent way to increase profit, and it is also beneficial to the Australian economic market.
Moreover, capital accumulation increases by innovation in the long-term economic market. Because of the development in investment, the increasing quantity of capital supply to supplement the invention. The creation supports technological development, and capital accumulation significantly affects the long-standing industry [11].

\subsection{Government spending}

The innovation growth has positively affected Australia when the government has increased supports. The government deficit is more significant than the government surplus. The government policy uses more extra funding to promote technological innovation, so corporation and individual are more proactive. When the education expenditure is relevant to the higher profession skill, employees or graduates could deduce the high portion of education expense. These expenses paid by the government's funding, so this policy favours labour improvement skills through education. It also prevents a lower innovation situation in Australia because the educated employee is the technical innovation source.

Similarly, the advanced skill workforce is the ascendancy when innovative industry wants to increase in Australia. When the productivity of production increases, it would promote a more effective technological revolution in labour activity.

The enormous educated employees or graduates are driven to obtain more skills, and college is a reliable choice. This side can increase one own capacity. Thus, it is a win-win for the individual and the market. Individual acquire more benefit for knowledge. For the technical innovation field, it would enhance productivity by increased of professional labour employment. The enlarged application of the degree of Master is an example. A more significant number of undergraduate wishes to qualify for a master. The postgraduates achieve the specified knowledge in the particular field and beyond the undergraduate. Therefore, the higher level of skilled workforce could enhance the incentive to innovate technically. For the future generation, advanced education incentives promote innovative knowledge and skills.

Furthermore, education needs to consider innovation improvement and sustainability because it can increase the creative competition to the innovative technology industry. The future generations can acquire the former generation's knowledge and skill, including their comments on the technological development or production. Based on the accumulation of knowledge and information, it is immeasurable for innovation development. When the technical innovation has an optimal outcome, the economic market's growth also occurs in good shape. 


\section{ISSUE}

Three fundamental headwinds towards Australian innovation development. Three reasons demonstrate that Australian innovation is experiencing a significant reduction shown in Figure. 2. Thus, economic growth has a negative influence.

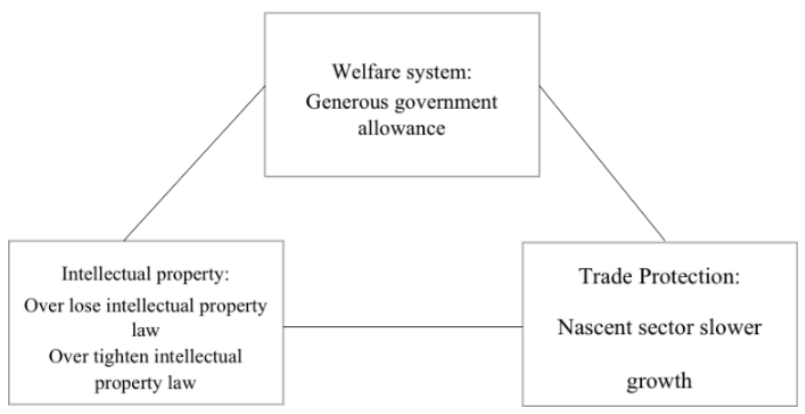

Figure. 2. Three fundamental headwinds towards Australia innovation development.

\subsection{Welfare system}

Firstly, Australia has a generous welfare system. Based on the data between 2015 to 2016, the Australian government spent $\$ 157$ billion on welfare funding, including $\$ 10$ billion for unemployment allowances. Compared with the $\$ 117$ billion welfare funding in 20062007, the average growth rate is $3.4 \%$. Based on the above information, Australia is the highest spending Organisation for Economic Co-operation and Development (OECD) county in social welfare and public benefit. Consequently, Australia's unemployment rate was higher by 10 per cent in 2017 [4]. The unemployed are prompt to receive the unemployment benefit, so numerous unemployed Australians prefer to stay at home [5]. For some unemployed individual, the allowance is more significant than salary. Because the government allowance supports the lower employment rate, the decline of employment impairs Australia's financial growth.

\subsection{Intellectual property}

Secondly, Australia's government over lose or tighten Australia's intellectual property law, neither of which is optimum.

When Australia's government much ease Australia's intellectual property law, the path of technical innovation become more complex. A considerable amount of human and capital resource spend on producing creative commodities because the new products with higher profit can reduce the spending of innovation by a corporation. For example, in the mobile devices industry and pharmaceuticals industry, replicating occurs simpler through the higher technological tool. When a corporation can quickly copy technological innovation, more companies are unwilling to innovate and shift to copy the product. Therefore, Australia's intellectual property law is an act to protect plagiarism and it fails to protect technical innovation [8].

From a different perspective, the government tighten the Intellectual Property Law that generates a low-profit outcome from the technical invention, further reduces the incentive to improve. Based on a monopoly, a company can make an abnormal profit by some unique patents. However, the small innovation business has less opportunity in the market because it strictly protects the patent. Ultimately, patents tend to be the commodities in the tightening patent system. If a small business tries to enter the market, it will pay the enormous license fee to monopoly with a unique patent. The vast spending in the growth stage disrupts the small business's initiative to improve innovation. Therefore, over loosening or tightening Australia's intellectual property law is questionable to stimulate innovation, reducing Australia economic growth.

\subsection{Trade Protection}

Finally, the Australian government policy of protecting local industries threaten technical innovation. The government's protectionism prevents the free trade market in Australia, destroying the economic market's invention [17]. The Australian government limits foreign products in the market, reducing the force of foreign competition in the domestic market. Therefore, domestic consumers have fewer alternatives to choose from when foreign goods are limited. Nevertheless, domestic suppliers have less motivation to pursue a higher profit within the market due to a limited investment into product innovation. It leads to a disadvantage for domestic companies and a reduction in economic growth.

For the infant industry, trade protectionism is a vital concern. Innovation has an essential role in the industry if the infant industry needs to create successful comparative advantages in the international market. However, the nascent sector would slower growth due to protectionism, which happens by the lower innovation and technology in the long-term economic market.

\section{CONCLUSION}

We began by reviewing the relevant social scientific literature associating with technical innovation and economic growth in Australia. Specifically, we have identified the benefits and problems between technological innovation and the economic framework related to government policies. Technical innovation and economic growth are a topic that has exceptional potential for academic researchers. Notable technical growth creates economic growth has generated considerable interest in the topic. Recent construct and measure 
development mean that government policymaker needs to consider the relationship between technical innovation and economic growth. From a government and corporation viewpoint, academic researchers can conduct research that can better technological innovation. More pragmatically, technical innovation has always been involved in research aiming to contribute to an active economic market. Because technical innovation and effective government policy are connected, technological innovation should invite scholars with various motivations and interests.

\section{ACKNOWLEDGMENTS}

The author thanks all family members and friends for encouragement and inspiration.

\section{REFERENCES}

[1] Australian Government Department of Industry, Innovation and Science. Australian Innovation System Report 2015. Australian Government Department of Industry, Innovation and Science, 2015.

[2] Australian Government Department of Industry, Innovation and Science. Review of R\&D Tax Incentive. Australian Government Department of Industry, Innovation and Science, 2016.

[3] Australian Government Department of Jobs and Small Business. Australian Jobs 2019. Australian Government Department of Jobs and Small Business, 2019.

[4] Australian Institute of Health and Welfare. (2017). Australia's welfare 2017: in brief. Australian Institute of Health and Welfare.

[5] Bajada, C. Unemployment and the underground economy in Australia. Applied Economics, 2005, 37(2), pp.177-189. DOI: https://doi.org/10.1080/0003684042000291335

[6] Carranza, J. Product innovation and adoption in market equilibrium: The case of digital cameras. International Journal of Industrial Organization, 2010, 28(6), pp.604-618. DOI: https://doi.org/10.1016/j.ijindorg.2010.02.003

[7] Creative Destruction and Firm-Specific Performance Heterogeneity. Cambridge, Mass: National Bureau of Economic Research, 2007.

[8] DeFeo, C., Harding, J., \& Wood, R. "No Genius Without Copying": How Loosening the "Tyranny of Intellectual Property Protection" Will Stimulate Innovation. In European Conference on Intangibles and Intellectual Capital, 2017, pp. 80-87. Kidmore End: Academic Conferences International Limited. http://search.proquest.com/docview/1906807097/
[9] Friedman, M. John Maynard Keynes. Economic Quarterly - Federal Reserve Bank of Richmond, 1997, 83(2), pp.1-23. http://search.proquest.com/docview/204893541/

[10] Hagedoorn, J. Innovation and entrepreneurship: Schumpeter revisited. Industrial and Corporate Change, 1996, 5(3), pp.883-896. DOI: https://doi.org/10.1093/icc/5.3.883

[11] Howitt, P., \& Aghion, P. Capital Accumulation and Innovation as Complementary Factors in Long-Run Growth. Journal of Economic Growth, 1998, 3(2), pp.111-130.

[12] Jahan, S., Mahmud, A., \& Papageorgiou, C. What Is Keynesian Economics? Finance \& Development, 2014, 51(3), pp.53-54. http://search.proquest.com/docview/1561748797/

[13] Larson, A. L. Sustainable innovation through an entrepreneurship lens. Business Strategy and the Environment, 2000, 9(5), pp.304. https://search.proquest.com/docview/213771054?ac countid $=12763$

[14] Lattimore, R. Research and development fiscal incentives in Australia: impacts and policy lessons. In OECD Conference on Policy Evaluation in Innovation, Paris, 1997, Vol. 26, No. 27, pp. 574 577.

[15] Miles, William, Miles, Grant, \& Snow, Charles. Collaborative Entrepreneurship: A Business Model for Continuous Innovation. Organizational Dynamics, 2006, 35(1), pp.1-11.

[16] Shionoya, Y. Joseph Alois Schumpeter: Entrepreneurship, Style and Vision. Journal of the History of Economic Thought. Cambridge University Press, 2004.2 DOI: https://doi.org/10.1080/1042771042000263876

[17] Thompson, W. R., \& Vescera, L. Growth waves, systemic openness, and protectionism. International Organization, 1992, 46(2), pp.493-532.E.M. Clarke, E.A. Emerson, Design and synthesis of synchronization skeletons using branching time temporal logic, in: D. Kozen (Eds.), Workshop on Logics of Programs, Lecture Notes in Computer Science, vol. 131, Springer, Berlin, Heidelberg, 1981, pp. 52-71. DOI: https://doi.org/10.1007/BFb0025774 